
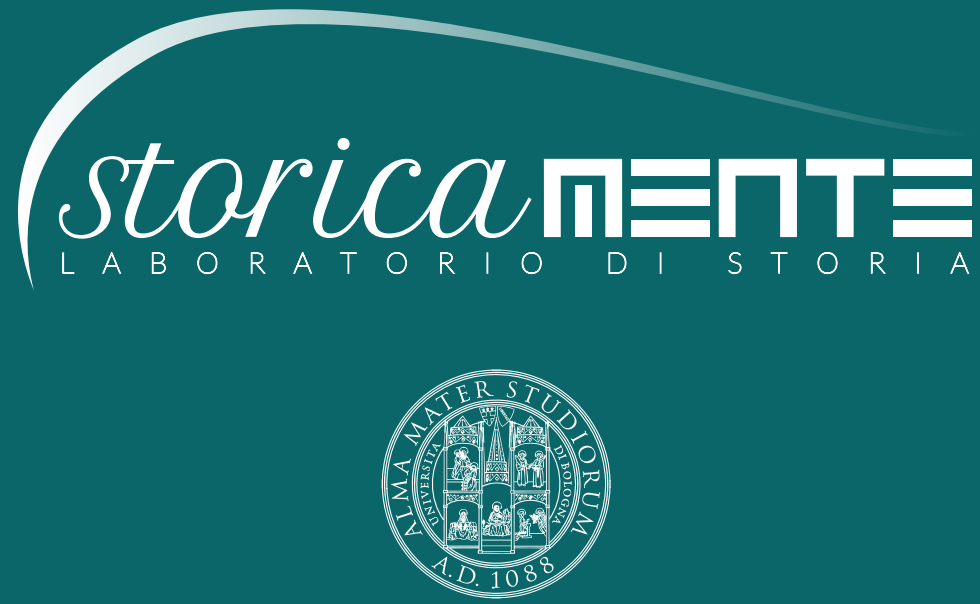

ALMA MATER STUDIORUM

Università di Bologna

Dipartimento di Storia Culture Civiltà

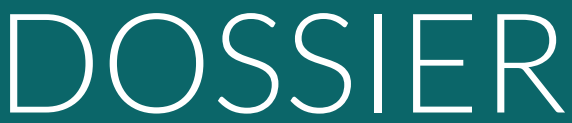

Representations of Fear in History

Empirical / Practical evidence and Methodological Issues 


\section{STORICAMENTE.ORG}

\section{Laboratorio di Storia}

Torben Möbius

World War II Aerial Bombings of Germany: Fear as Subject of National Socialist Governmental Practices

Numero $11-2015$

ISSN: $1825-411 \mathrm{X}$

Art. 21

pp. 1-21

DOI: $10.12977 /$ stor606

Editore: BraDypUS

Data di pubblicazione: 31/12/2015

Licenza: CC BY-NC-ND 4.0 International

Articolo sottoposto a revisione paritaria a doppio cieco

Dossier: Representations of Fear in History: Empirical / Practical evidence and Methodological Issues edited by Vito Gironda, Marica Tolomelli 


\title{
World War II Aerial Bombings of Germany: Fear as Subject of National Socialist Governmental Practices*
}

\author{
TORBEN MÖBIUS \\ Bielefeld University \\ Bielefeld Graduate School in History and Sociology
}

(BGHS)

This paper highlights how the National Socialist regime in Germany created the so-called "Selbstschutz" ("self protection») in civil air defense as an "apparatus of society" (Michel Foucault) to educate the German population with regard to the new possibility of aerial bombing. Mechanisms, functions of emotional control and their relationship to concrete practices of the people involved are shown alongside a local example. Regarding the spread and development of fears, this article maintains that practices of "Selbstschutz" had to bridge the temporal gap between future expectations and actual experiences in crucial ways. Before the war, "Selbstschutz" followed its own logic of expectation of danger and risk, as exemplified in aerial-defense simulation exercises, which clashed with the reality of bombs falling on German cities later on.

\section{Fear and Air War}

The basic emotion of fear and anxiety ${ }^{1}$ may very well be considered a

\footnotetext{
* The author would like to thank Julia Engelschalt (Bielefeld University) for her translation of this article.

1 Fear and anxiety are frequently used together. Since the German term «Angst» is the one most used in my sources, I will focus on fear, which I understand here as the anticipation of an undesirable event which is believed to happen in the future.
} 
ubiquitous phenomenon of human existence [Ben-Ze'ev 2000, 474489]. However, fear is not merely an anthropological constant guiding human action according to a simple stimulus-response model. Two basic assumptions underwrite historiographical accounts of fear: first and foremost, fear is always and inevitably historical, meaning that its social and cultural conditions, functions and effects change across time and space. Secondly, fear was and continues to be an emotion of great historical impact as well as the origin of both reflections and negotiations [Hitzer 2011; Bourke 2005].

Especially in modern mass societies of the belligerent "age of extremes» (Eric Hobsbawm), both individual and collective fears played an important role in political contexts. Fear increasingly became the object of governmental efforts. In German history, the taboo of public negotiation or reflection of this emotion was not removed until very recently. It was not until the second half of the 1950s and the beginning of the anti-nuclear movement that fear became an explicit part of public discourse and even came to serve as a justification for political claims. Throughout the «Third Reich» and during the early years of the Federal Republic, this emotion had been stigmatized or even pathologized [Biess 2009, 242f.]. That notwithstanding, of course, fears always existed and were crucial to emotional regimes in modern states.

Particularly during the age of air war and aerial bombing against German cities in the Second World War, the collective fear present in civil society needed to be addressed by the National Socialist state. In the sense of Michel Foucault's concept of "governmentality", the modern state was facing a fundamentally new problem with regard to the art of government ${ }^{3}$. In the context of air war, the government had to develop

2 Following Martha Nussbaums classical definition, I here define emotions as «appraisal or value judgment $[\mathrm{s}]$, which ascribe to things and persons outside the person's own control great importance for that person's flourishing» [Nussbaum 2001, 4].

3 «The ensemble formed by the institutions, procedures, analyses and reflections, the calculations and tactics that allow the exercise of this very specific albeit complex 
new strategies both of protecting and producing its citizens. Beyond that, in contexts of security, the German case is specific in that the political pursuit of security, of «Ruhe und Ordnung» ("quiet and order») played a central role in the political culture of modern Germany [Lindenberger 2001]. The beginning of World War I, and particularly the first aerial bombings, marked a moment of fundamental disturbance of this desire. At this point, and increasingly during the interwar period, the "homefront» - meaning civilians both at their workplaces and in their homes - became a veritable issue in military discourse [Süß 2011, 27-30]. Therefore, in reaction to this new danger to society in general, new concepts of civil air defense were established and became a political field in their own right [Fritzsche 1992]. The governance of emotions - particularly, fear - constituted a key aspect in this context. Not only was the state no longer able simply to conceptualize its population as a passive entity under the guidance of state institutions; the regime also depended on efforts made by all civilians in order to overcome the air war. In line with the National Socialist notion of «Volksgemeinschaft» («people's community»), every "Aryan» German at the homefront was expected to help in reaching this aim in both mentally and physically active ways ${ }^{4}$.

Based on the above-mentioned reflections by Foucault, the present article focuses on the contemporaneous notion of «Selbstschutz» ("selfprotection»), meaning the inclusion of civilians in resisting the expected air raids, as an essential part of civil air defense. "Selbstschutz», here, will be understood as an "apparatus of security» which, on the one hand, consists of an ensemble of organized practices, or techniques, used by the modern state in governing its population. On the other hand, this

form of power, which has its target population, as its principal form of knowledge political economy, and as its essential technical means apparatuses of security» [Foucault 1991, 102].

4 See the different contributions of military experts and Nationals Socialist politicians in Knipfer, Hampe 1937. 
«apparatus of security» represents both mental and physical practices displayed by the civilians themselves. Both dimensions - which, as I argue, interact with and reproduce each other - are pervaded by powerful and highly ambivalent emotions, most notably, fear.

Focusing on the city of Bielefeld ${ }^{5}$ in East Westphalia, this article addresses the following questions: firstly, what are the forms of fear and the resulting practices during the phase of training for «Selbstschutz» in the 1930s and, subsequently, during the «real» situation of bombs falling in World War II? And, secondly, what were the specific ways, i.e. functions and mechanisms used by the National Socialist regime to govern those fears and practices? In order to answer these questions, I begin by defining the historical concept of «Selbstschutz» before analyzing the concrete example of the "Luftschutzgemeinschaft» ("community of air defense») as it was established in Bielefeld. Finally, I will give a brief conclusion and an outlook on «Selbstschutz» during the Cold War period.

\section{Visions of 'Self Protection'}

Visions of a forthcoming war already existed since before the First World War, yet the first real - albeit limited - air bombings which occurred during the war created a heightened level of anticipation [Süß 2011, 31-37]. In Germany, these visions were closely connected to a militaristic and affirmative notion of war in right-wing political circles. Also, the construction of the first zeppelins sparked widespread German enthusiasm for aviation in general. This enthusiasm was loaded with nationalist implications. Not only did people celebrate the «conquest of the air» by German aviation pioneers as a national awa-

5 Bielefeld became an "explicit target in battle planning» in the summer of 1941 [Vogelsang 1994, 5]. 
kening, but simultaneously, Germany's geographic location became a problem in the face of a potential threat from above [Fritzsche 1991, 201]. The First World War then delivered a first, indisputable proof of the destructive potential of airplanes armed with bombs. Now, the bombings - while remaining locally and technically limited - resulted in a spread of fear among the populations of cities such as London or Cologne [Süß 2011, 28-30].

The first concrete political reactions occurred during the Weimar years. For instance, newly established lobby groups advocating civil air defense called attention to the new threat and demanded political action in this domain. The aspect of civil air defense gained importance as an integral part of military expertise. At the same time, the focus on civic participation was constantly reinforced by emphasizing the need to overcome the air-war challenge as a "people's community". The "Deutsche Luftschutzliga» ("German Air Defence League») and similar militaristic organizations emerged with a nationalistic or even racial impetus as part of the right-wing politics against Weimar Republic [Lemke 2005, 98-166; Fritzsche 1991, 133-184].

«Selbstschutz» was the term used in reference to those aspects of civil air defense which required the participation of civilians. As an «apparatus of security", the concept increasingly became integrated into the agenda of the National Socialists after their takeover in 1933. It should be noted at this point that the National Socialist notion of the able-bodied and racially pure "Volksgemeinschaft» was not merely understood in a defensive way. The exclusionary aspect of this term was conceptualized in close connection to the aggressive and expansionist notion of «Kampfgemeinschaft» («battle community») [Peukert 1982]. "Selbstschutz» denoted both the behavior and the practices to be carried out by every dutiful citizen before, during and after an air raid. After 1933, those practices were rehearsed in urban public spaces, and they played a prominent role in expert discourses and political communication. In contrast to the intuitive semantics of "Selbstschutz", the term thus 
referred to collective measures of protection. In that sense, the "people's community» played a crucial role within the political field aimed at the production of «totality» [Steber, Gotto 2014]. Absolutely everybody who was not fighting as a soldier, "from children to old men", had to be able to react to bomb attacks in urban areas in a pragmatic and even heroic way, and needed fit into the "große System des Selbstschutzes, in diese Front der Kämpfer der Heimat [great system of self-protection, into the homefront of fighters, transl. the author]» [von Roques 1937, 247]. Women were imagined not only as active participants, but even as leaders of the "Selbstschutzkräfte» («agents of self-protection»). This, of course, had little to do with feminist ideas of emancipation, but was due to the demographic fact that few men were left to fight at the home front during the war.

In terms of organizational structure, «Selbstschutz» was conceived along the lines of an organic model: from the "Luftschutzgemeinschaft» ("air raid home community») as the smallest unit to the "Luftschutzgemeinschaft» of the city at large. The "Reichsluftschutzbund» (RLB) was founded immediately after the takeover as the single largest National Socialist organization ${ }^{6}$. It was responsible for educating the population on all issues related to aerial defense and coordinated the "Selbstschutz" up until the last months of war, before the NSDAP took control over this governmental field [Nolzen 2007].

The aim was to create a widespread "Luftschutzbereitschaft» («readiness for air defense»). To a general «airmindedness», which had existed in the German public sphere since imperial times, fascism added a new layer of enthusiasm for aviation and technology at large. From now on, civilians were to be trained to react to the constant risk of air war in terms of both mental and physical readiness to protect themselves

6 At the beginning of the war, the RLB had 15 million members: Süß 2011, 45. The local group in Bielefeld had 23.271 members and 2.052 officials. See Westfälische Zeitung, Aufbau und Organisation, August 5, 1939. 
as a "people's community». From the early 1930s on, thus even before the war, "Selbstschutz» practices began to pervade every aspect of daily life. Basements had to be transformed into impromptu bunker rooms. The potential «Selbstschutzkräfte» had to participate in training courses (which, ironically, were declared as "voluntary»), or they had the option of becoming official members of the «Reichsluftschutzbund», which trained, guided and exerted control over «Volksgenossen» («members of the people's community») in all aspects related to "Selbstschutz». Through public mass exercises and rehearsals, bomb dummies, posters and special magazines, the anticipated air war slowly but steadily gained omnipresence in the urban public sphere.

\section{Practices of 'Self Protection': A short local Case Study}

The education of air defense forces towards "Luftschutzbereitschaft» already began in the early 1930s in the form of public exercises. They were staged in public squares or even across larger urban areas. As a consequence, air defense began to exert a significant influence on life in large German cities at an early stage of National Socialist rule. Public exercises were carried out as performances by more or less professionalized air defense forces. They were mostly targeting bystanders as a random and spontaneous group of potential «Selbstschutzkräfte». Besides the distribution of practical knowledge, an important aspect was the constant repetition of such (and similar) rituals. In doing so, the "Volksgenossen» were constantly reminded of the potential threat, and thus, sensitized and activated for actual cases of emergency.

7 Peter Fritzsches appropriate notion of «airmindedness» is defined as «the full-scale mobilization of the population according to the ideological principles of National Socialism under the pretext of adhering to supposedly self-evident military and technological requirements necessary for national survival in the air age» [Fritzsche 1991, 190]. 
In the spring of 1937, local newspapers reported on a spectacular aerial defense exercise which had taken place on a square near the city hall the previous day. One of the numerous photographs illustrating the press coverage shows young members of the Hitler Youth at play. In the background, one can see a marching band of the same youth organization as well as numerous spectators. What makes this image particularly interesting is that the children - boys playing tug-of-war, girls engaging in a ball game - are equipped with gas masks, the socalled "Volksgasmasken» or "VM 37»". They were thus subject to a process of visual normatization, representing the "Kampfgemeinschaft" in a gruesome way. Beyond this representational function, however, the exercise also served a rather practical purpose of behavioral control. Bystanders were encouraged to purchase this particular, new model of gas mask, which was said to protect the "Selbstschutzkräfte», not only from actual gas attacks, but also from the smoke ascending from houses burning after an air raid. Besides the advertisement for a particular product, a further function of the exercise was to normalize both the air war itself and its dangers, to inscribe it into the daily life of all citizens including children. If even they were able to follow their daily routines while wearing gas masks, thus the subtext transmitted by the demonstration, adults should find it easy to do the same.

Nevertheless, the intention of such exercises was not to trivialize the danger and the issues at stake. In the aforementioned article, the image of playing children is followed by that of a demonstration of professional air defense forces, who were shown practicing real-life "Selbstschutz» situations such as fire extinction, in order to give the impression of security. Even in this case, however, the focus of interest was much more on the performative aspect of visibility and on the internalization of the danger lurking above than on the practical learning effect. The

8 Since 1937, every single civilian should have been equipped with this professional protection mask, which was available in three sizes [Fritzsche 1991, 211]. 
«danger from above» in general, and especially the militaristic and revanchist politics of the National Socialist Regime, were meant to become normalized even in the sphere of urban daily life.

Blackouts in urban areas were another field of intense training and preparation which pervaded daily life. According to Marc Wiggan's comparative analysis of German and British aerial defense efforts, blackouts served two purposes, regardless of whether they occur before or during wartime. Firstly, they were meant as a physical defense: a totally darkened city was thought to be invisible for enemy bombers. Secondly, they were meant to establish «a community spirit, or ethic, that would help their populations to survive a bombing war.» [Wiggan 2011, 43] Focusing on Nazi Germany here, the alleged need for «totality» in the field of «Luftschutz-Selbstschutz» was allegorically repeated in regulations for blacking out the city ${ }^{9}$. Even just one "Volksgenosse» disregarding blackout regulations, thus the public discourse, would potentially cause harm to an entire city. A lack in "Luftschutzbereitschaft», in that sense, also was an immediate offense causing harm for the entire «Volksgemeinschaft». Furthermore, in contrast to other security measures, blackouts could be monitored rather easily. It would seem safe to assume that blackout policies were enacted throughout and until the very end of the war because they provided a means of ensuring constant mobilization among the population. This is particularly striking when considering the fact that blackouts were still carried out after they had become obsolete in the face of new ranging techniques.

This particular sub-field of «Selbstschutz» was exceptional in that it functioned via the conscious evocation of fear which, in turn, would

9 Dietmar Süß provided the first systematic attempt of a comparative sociohistorical analysis of the societies of National Socialist Germany and liberal democratic Britain during air war. Regarding governmental strategies, both states created a community spirit in order to prepare their respective populations for air bombings. The National Socialist apparatus of society was not only a defensive governmental mechanism to control the people, but it was part of the concept of «Volksgemeinschaft» and part of both an exclusive racial politics and a militaristic imperial agenda [Süß 2011]. 
lead to a certain type of security-oriented behavior. Apart from that, urban blackouts meant a step back into the pre-modern era not only in a symbolic sense. After all, street lighting at night had been a governmental strategy of warranting security in urban spaces. A darkened city is well known to provide a hunting ground for thieves and other criminals. This side-effect was countered by the National Socialist regime by using all the ideological and repressive means it could muster, including death penalty for perpetrators ${ }^{10}$.

Seeking shelter in case of an alarm - the second most important duty of «Selbstschutzkräfte» next to obeying blackout regulations - remained an unsolved problem. The government staged aerial defense exercises with the purpose of training civilians for this case. Particularly daytime alarms would bring daily life to a complete halt: people in the streets and in their homes would have to abandon any activity and seek shelter in the nearest bunkers. Both the Reichsluftschutzbund and the NSDAP issued explicit orders prohibiting the breakout of mass panic in accordance with the "Ruhe und Ordnung" doctrine". However, in contrast to the "Luftschutzhausgemeinschaften", public shelters and bunkers brought together people of all kinds of social background. Here, the ideal of a homogeneous "Volksgemeinschaft» threatened to clash with reality. Already before and, more frequently, during the war, there were reports and complaints about wrongful and disrespectful behavior in shelters ${ }^{12}$. In wartime, it was particularly bunkers which became

10 Looters "prove themselves undeserving of being a part of the German people's community. Therefore, he shall be sentenced to death.» Bericht des Landgerichtspräsidenten: Die Gerichtsbehörden in Bielefeld während des Krieges, in: Bielefelder Kriegschronik 1939/1940 (Teil 1), 169, Stadtarchiv Bielefeld 300,11, 1. Nr. 1.

11 Newspapers played a crucial role in distributing knowledge on such matters. Generally speaking, air defense took up an increasing part of newspaper coverage in the 1930s. The focus was not only on informing the people; there was also detailed coverage of exercises after the event. See, for instance, Bomben auf Bielefeld, "Westfälische Neueste Nachrichten", January 26, 1939.

12 See the report on the chaotic conditions in a public shelter: Schreiben Otto Stra- 
spaces of emotional response, particularly fear, and of National Socialist exclusion [Süß 2011; Buggeln, Marszolek 2008].

The provision of safe shelters in private homes was of growing importance and, at the same time, became increasingly problematic. Due to scarcity in resources, it turned out to be impossible to provide safe shelters for the entire population. The «Luftschutzkeller» («bombing protection basement»), i.e. a remodeled basement room underneath a residential home or condominium, was the most important spatial arrangement when it came to seeking shelter. The "Luftschutzhausgemeinschaft» assembled in those spaces to wait for the end of an alarm or air raid. An exciting change in daily routines, the procedure of going downstairs under the guidance of the "Luftschutzhauswart» («air defense supervisor») quickly turned into an inconvenient chore. Particularly during the first months of war, and during the years of 1940-1941, the residents of Bielefeld spent a great amount of time in their respective shelter basements without bombs actually falling. The resulting reactions oscillated between fear, dullness and indifference. Many civilians began to disobey the order of going downstairs in case of an alarm.

Active "Selbstschutzkräfte», who would be the ones fighting against the «Brandbombe» ("fire bomb») during actual air raids, were theoretically and practically trained in so-called «Luftschutzschulen» ("aerial defense schools»), where they also had to become physically active. Interestingly, these training sessions were structured in such a way that, "psychologically speaking», exercises were just risky enough so as not to cause any physical harm or induce generalized fear or panic. Paradoxically enough, the reality of war was not to become all too real. To illustrate this paradox, consider the following example: a widely publicized field report recounts an exercise during which a group of overly enthusiastic RLB members were crawling through a barb-wire tunnel 
while wearing gas masks. Although the exercise in itself was relatively dangerous, their supervisor reportedly used tear gas to make the exercise even more "realistic", thereby exposing the trainees to an even higher level of risk. Similarly, there are several reports indicating that participants in "Selbstschutz» rehearsals were repeatedly injured by fake or even real fire bombs. The Reichsluftfahrtministerium («Ministry of Aviation») eventually prohibited such brutal practices on the local level because they would deter "Volksgenossen» from participating in air defense altogether. The paradoxical nature of this assessment on the part of the government exemplifies the ambivalent nature of fear. After all, exercises using the now-forbidden fire bombs did come rather close to the reality of an air war which would begin very soon. The maintenance of security, and thus, "Luftschutzbereitschaft» in the present was thus deemed more important than security in a projected future scenario. "Selbstschutz» had become stabilized as a risk-free security apparatus following its own internal logic. This intrinsically paradoxical system was doomed to fail with the beginning of British air attacks against the "German Reich».

Fear and security are thus always inscribed in concrete temporal imaginaries. Between the wars, air war was conceptualized within the framework of a complex, unstable and unpredictable set of expectations. «Selbstschutz», with its simulation games and exercises, thus created a certain level of experience among the population. Although this experience was based on expertise generated from the aforementioned expectations, the reality of bombings was very different from theoretical musings and also from the practical simulation exercises ${ }^{13}$.

This was exactly what happened in Bielefeld after 1941. The "Selb-

13 The air war, fear and «Selbstschutz» are all embedded in imaginaries of time, between the "horizon of expectations» and the mostly simulated "space of experience» [Koselleck 2004]. 
stschutzkräfte» had to prove themselves under real-life conditions ${ }^{14}$. From then on, the fear of suffering physical harm or of losing one's livelihood was based on material, physically tangible dangers and experiences and could no longer be avoided through governmental means of risk minimization or through the simple act of non-participation in «Selbstschutz» exercises. When people began to realize that they were facing a life-or-death struggle, this was the first time that widespread fear became an actual problem for the NS security administration. The «Selbstschutzkräfte» now had to be directed in such a way that they were willing to face danger at the risk of losing their lives so as to prevent even greater damage to the urban "Luftschutzgemeinschaft». With the onset of British air raids, the most important arena of «Selbstschutz» was the fight against fire bombs, a problem which created massive fear among "Selbstschutzkräfte» until the very end of the war. Already during an ongoing attack, active «Selbstschutzkräfte» were to observe the events from their respective basement under the guidance of their supervisor in order to become active in case their own house was hit by a bomb. The first fire bombs were built in such a way that they would fall through the roof and further floors of a residential home before setting fire to furniture and other flammable materials over the course of several minutes.

In such cases, the «Selbstschutzkräfte» had to use the most simple tools - home-made devices such as sand-filled buckets, the so-called «Feuerpatsche» («fire beater») and the "Luftschutzhandspritze» («air defense nozzle») - to extinguish the surrounding fires before turning to the burning bomb itself. This meant crawling towards the bomb, all the while wearing provisional protection gear and, ideally, the «Volksgasmaske»; extinguishing the bomb with sand; or even carrying it out-

14 In sparsely or unpopulated areas of the city, such as Gadderbaum, «Selbstschutz» was carried out in its pre-war form until 1944. See Einsatzübungen der Selbstschutzkräfte im August 1944, Stadtarchiv Bielefeld 130,9/Gemeinde Gadderbaum, 1. Nr. 2497. 
side. Needless to say, this procedure was highly dangerous and potentially lethal - especially considering the fact that fighter jets ejected exploding bombs along with fire bombs in order to cause even greater damage and to deter the «Selbstschutzkräfte».

Sources confirm that fears were pervasive; for instance, newspapers, placards as well as Reichsluftschutzbund and NSDAP events repeatedly stressed the importance of showing courage when dealing with the bomb. This was achieved by construing the bomb as virtually harmless - all one had to do in order to dismantle the threat from above, thus the public discourse, was to approach it in a head-on manner. Even though daily newspapers simultaneously evoked well-crafted narratives of heroic behavior ${ }^{15}$, it is safe to say that there was an overall tendency of using what the sociologist Wolfgang Bonß has aptly called «Abkürzungsstrategien» («strategies of abbreviation»), which are characteristic of modern security politics in general [Bonß 1997]. These strategies are used in this context to overcome the challenges of a complex social reality and especially the dangers and insecurities of modern technology. Modern warfare and the air war meant a massive threat to the specific German fixation on security.

As long as there were only few bomb impacts in Bielefeld, the "Selbstschutz» remained functional with the help of such governmental strategies, even though remaining fears still needed to be dealt with. In the event of larger attacks, which combined fire and exploding bombs, this was no longer possible. «Selbstschutzkräfte» were fearing for their lives in such a way that they would not leave their shelters and bunkers, which meant that they did not extinguish fires or dismantle the bombs. The disappointment expressed by the mayor of Stuttgart, "[d] er Selbstschutz hat versagt [Selbstschutz has failed]», is certainly true for

15 See, for example, the report of an 8o-year-old invalid who allegedly defused three bombs, one of them by rolling it into a carpet and carrying it out of the house with his bare hands. See Zwei alte Schildescher bewährten sich bei der Bekämpfung von Brandbomben, «Westfälische Zeitung», October 19, 1940. 
Bielefeld as well [quoted in Kramer 2011, 157].

As a consequence, «Selbstschutz» was restructured across the "Reich». From 1942 on mobile units were responsible for several houses at once, and their members generally had a higher level of experience and professional know-how [Beer 1990, 28]. At the same time, the narrative strategy of public discourse moved away from its former, idealized way of describing the fight against the bomb as an heroic act. Instead, the shelter basement increasingly became the central spatial arrangement framing the practices of «Selbstschutz». Particularly since individuals were frequently trapped in shelters due to the density of the attacks and the increasing weight of individual bombs, fear came to be almost entirely confined to those close quarters. The shelter had lost its status as a safe harbor and space of heroic resistance.

The agenda of aerial defense was adapted accordingly, and «Volksgenossen» - who were thereafter addressed as individuals - received advice for "Selbsthilfe» ("self-help»). This included, among other things, tips on breaking through walls and escaping from basement rooms which all too often turned into life-threatening furnaces. «Selbstschutz», including its earlier heroic depiction of serving the community, began to vanish from public discourse. Instead, perseverance and the ability to escape from shelters gained more and more importance ${ }^{16}$. At the same time, the NSDAP, which took over a great deal of tasks related to air defense from the RLB, began to organize paternalistic care of those who had been bombed out. Here, we can observe a structural change from a focus on preventive measures and a crucial position of the population as an actor in aerial defense towards concrete, material help for bombedout people through public administrative bodies [Süß 2011, 226-237]. The task of fire extinction was conferred to more or less professional

16 See Phosphor. Deine Selbsthilfe im Bombenkrieg, "Westfälische Neueste Nachrichten», August 7, 1943. Here, the Volksgenossen were addressed directly: «It sure takes a lot of courage to help yourself in the bomb war - but you've got that courage, don't you?» 
security forces. Women, who had worked as «Luftschutzhauswartinnen» and fighters in "Selbstschutz», had been removed from leading positions in the "Luftschutzhausgemeinschaften" since the beginning of the war [Kramer 2011, 118-124]. Once more, they were reimagined as being overly emotional in the sense of hysteria and fear. "Psychological reasons» were given to justify the fact that men were once again assigned leading positions in aerial defense. The role of women was limited to emergency relief and care work inside the shelters and after bomb attacks ${ }^{17}$.

In the midst of the ongoing air war, Bielefeld experienced a paradox which bears interesting implications for the history of security and emotions. As the rather quiet year of 1942 progressed, there was a significant decrease in "Luftschutzbereitschaft» and, along with that, in collective fear, which led to even the most fundamental aspects of «Luftschutz-Selbstschutz» being neglected. Despite repeated alarms, people no longer took to the bunkers and shelters, but instead - as one exemplary source indicates - continued to watch a theater performan$\mathrm{ce}^{18}$.

The temporary, and certainly paradoxical disappearance of fear can be grasped with the help of Niklas Luhmann's notion of «expectational security» [Luhmann 1995, 303-307]. Along those lines, Bielefeld's population was experiencing a typical pattern of coping with insecurity: the danger, which was no longer perceived as manifest yet still existing, was blanked out, which resulted in the neglect of practices which had previously been carried out in order to ensure security among the «Volksgemeinschaft». The result, in Luhmannian terms, was a reduction of complexity in the face of future insecurity [Bonß 1997, 24f.].

17 Schreiben des RMdL an das Präsidium des RLB vom 30.9.1940, Stadtarchiv Bielefeld 130,9/Gemeinde Gadderbaum, 1. Nr. 2492.

18 Stadtheater Bielefeld - Rückblick auf die 5. Kriegs-Spielzeit 1943/44, Stadtarchiv Bielefeld 300,11, 1. Nr. 8, Kriegschronik 1944, 238. 
When the air war returned to Bielefeld with two massive bombings in January and September of 1944, the collective strategy of coping with fear had changed once more. This time, the discourse was centered around the idea of a transcendent fate, according to which a morally superior «Volksgemeinschaft» could no longer put up a fight against the brutal acts of crime committed by the allied "Luftgangster» ("air gangsters») 19. The "Volksgenossen» were told to simply remain perseverant - after all, the deaths of others should not have been in vain. The "Endsieg» ("final victory»), as vague and indeterminate as it remained, was at the heart of a narrative of deliverance and resurrection awaiting those who were able to hold out for a better future. The fear of the "Selbstschutzkräfte» was no longer the target of governmental strategies; the security apparatus had collapsed along with the overall governmental regime of emotional control ${ }^{20}$.

\section{Conclusion and Outlook}

Individual and, even more importantly, collective emotions were a crucial object of governmental practices in the era of National Socialism. Air war and the need to cope with this new form of warfare on the level of the entire society became problematized and publicized. Along with the emergence of a body of prognostic knowledge regarding these new techniques of warfare, «Selbstschutz» in the context of civil air defense developed as a security apparatus of National Socialism. In everyday urban life, this apparatus urged citizens to acknowledge the fact that they were in danger, and to share and distribute practical

19 The most popular book on the air war in Germany is still Jörg Friedrich's, where he has articulated this long-lived narrative of victimization: Friedrich 2006.

20 See the report on a mass funeral after a massive attack: Sie starben nicht umsonst, "Westfälische Zeitung», January 18, 1944. 
knowledge. Furthermore, they were trained to follow strict practical routines, under the assumption that this would keep fear in check or even channel such emotions into productive driving forces. Yet even beyond the aspect of maintaining security, «Selbstschutz» ultimately aimed at activating the "people's community» for the purpose of waging a war of conquest and extermination.

In contrast to, for instance, the development in Great Britain, the German case was underwritten by an imagination of a coming war as a potentially positive force which would recreate society or community. Great Britain did adopt measures of civil air defense to define and organize the duties of civil society in this context. However, what was certainly missing in liberal democratic societies was an equivalent to «Selbstschutz». The National Socialist apparatus of security had the function of creating the "Volksgemeinschaft» within the smaller units of urban communities of aerial defense through daily routines. The idea of a "total», heroic and soldierly fight at the "homefront», even in peacetime, was a specifically National Socialist phenomenon. Moreover, German «Selbstschutz» is different from the British notion of the "people's war» in its exclusionary dimension.

«Selbstschutz» thus emerged between the wars as a field of politics and actions of securitization which followed its own internal logic of predictions and which became increasingly self-sustaining. However, when the predicted future became a reality in the sense of actual war and bombs falling on German cities, this elaborate system of training and preparation failed.

Nevertheless, the fight against and governance of fear did not take on forms of total control, constraint or mere propaganda at any point in time during the "Third Reich». Instead, we can observe rather subtle forms of behavioral control aimed at nipping fear in the bud, which was perceived as necessary in order to keep citizens from turning away from the issue of air defense. Furthermore, techniques of governance were malleable and adjusted according to the changing circumstances. 
The idealized, amateur «Selbstschutz» of the pre-war era was restructured and professionalized once air war had become a reality with which aerial defense communities had to cope. The dispositive became destabilized in the face of the sheer masses of people who had lost their homes as a result of air raids. In the situation of massive aerial bombings, the last in a series of adaptations - resulting in the disappearance of "Selbstschutz» - can be described as an increasingly transcendent construction of the Germans as victims of war crimes. This myth of victimization, which was first established by Joseph Goebbels, survived the war and was particularly powerful during the early years of the Federal Republic, when the air war was preserved in collective memory as having demonstrated the great capacity of the "Volksgemeinschaft» to cope with losses and suffering.

While «Selbstschutz» in its original form was abandoned after 1945, the term gained renewed importance during the Cold War period. Within the context of governmental and municipal structures of security politics in case of war and catastrophe, it now included citizens' individual practices of self-protection. For instance, campaigns of Civil Defense in the 1960s addressed those individual actions which were necessary to survive a nearby nuclear strike. However, the cultural implications of National Socialist «Selbstschutz» no longer existed. It was neither shaped by militaristic or heroic images, nor was it a mechanism of social exclusion anymore. Of course, governmental techniques during the "post-heroic age» (Herfried Münkler) were still targeting fears on both the individual and the societal level. However, it should be noted that the security apparatus was no longer used to justify any kind of militaristic education of civil society in times of peace, but that it was only reactivated in cases of emergency. Eventually, fear would come to be articulated not only in scenarios of a looming war, but also in the sense of a distinctly political concept, as can be observed for the context of the emerging peace and anti-nuclear movements. 


\section{Sources}

Newspapers:

"Westfälische Neueste Nachrichten»

«Westfälische Zeitung»

\section{Archive (Stadtarchiv Bielefeld):}

Stadt AB 300,11, 1. Nr. 1.

Stadt AB 108,7/Hochbauamt, 1. Nr. 240.

Stadt AB 130,9/Gemeinde Gadderbaum, 1. Nr. 2497.

\section{Bibliography}

Beer W. 1990, Kriegsalltag an der Heimatfront. Alliierter Luftkrieg und deutsche Gegenmaßnahmen zur Abwehr und Schadensbegrenzung dargestellt für den Raum Münster, Bremen: Hauschild.

Ben-Ze'ev A. 2000, The Subtlety of Emotions, Cambridge, Mass.: MIT Press.

Biess F. 2009, "Everybody has a Chance»: Nuclear Angst, Civil Defense, and the History of Emotions in Postwar West Germany, "German History», 27 (2): 215-243.

Bonß W. 1997, Die gesellschaftliche Konstruktion von Sicherheit, in Lippert E. (ed.) 1997, Sicherheit in der unsicheren Gesellschaft, Opladen: Westdeutscher Verlag, 2141.

Bourke J. 2005, Fear. A Cultural History, London: Virago.

Foucault M. 1991, Gouvernmentality, in Burchell G. (ed.), The Foucault Effect: Studies in Governmentality. With two Lectures by and an Interview with Michel Foucault, Chicago: Chicago Uni. Press, 87-104.

Friedrich J. 2006, The Fire: The Bombing of Germany, 1940-1945, New York: Columbia Univ. Press.

Fritzsche P. 1992, A Nation of Fliers: German Aviation and the Popular Imagination, Cambridge, Mass.: Cambridge Univ. Press.

Hitzer B. 2011, Emotionsgeschichte - ein Anfang mit Folgen, «H-Soz-Kult», <http:// www.hsozkult.de/literaturereview/id/forschungsberichte-1221>.

Knipfer K., Hampe E. (eds.) 1937, Der zivile Luftschutz. Ein Sammelwerk über alle Fragen des Luftschutzes, Berlin: Stollwerk (I ed 1934).

Koselleck R. 2004, "Space of Experience" and "Horizon of Expectation": Two Historical Categories, in Koselleck R. 2004, Futures Past. On the Semantics of Historical Time, 
New York: Columbia Univ. Press., 255-275.

Kramer N. 2011, Volksgenossinnen an der Heimatfront: Mobilisierung, Verhalten, Erinnerung, Göttingen: Vandenhoeck \& Rupprecht.

Lemke B. 2005, Luftschutz in Großbritannien und Deutschland 1923-1939. Zivile Kriegsvorbereitungen als Ausdruck der staats- und gesellschaftspolitischen Grundlagen von Demokratie und Diktatur, Munich: Oldenbourg.

Lindenberger T. 2001, Ruhe und Ordnung, in François E., Schulze H. (eds.) 2001, Deutsche Erinnerungsorte, vol. II, Munich: Beck, 469-474.

Luhmann N. 1995, Social Systems, Stanford: Stanford Univ. Press.

Marszolek I., Buggeln M. (eds.) 2008, Bunker: Kriegsort, Zuflucht, Erinnerungsraum, Frankfurt-New York: Campus-Verlag.

Nolzen A. 2007, Politische Führung und Betreuung der Bevölkerung. Die NSDAP im Bombenkrieg, 1939-1945, in Lemke B., Brinkhus J. (eds.) 2007, Luft-und Zivilschutz in Deutschland im 20. Jahrhundert, Potsdam: Militärgeschichtliches Forschungsamt, 89-108.

Nussbaum N. 2001, Upheavals of Thought: The Intelligence of Emotions, Cambridge: Cambridge Univ. Press.

Peukert D. 1982, Volksgenossen und Gemeinschaftsfremde: Anpassung, Ausmerze und Aufbegehren unter dem Nationalsozialismus, Köln: Bund-Verlag.

Steber M., Gotto B. (eds.) 2014, Visions of Community in Nazi Germany: Social Engineering and private Lives, Oxford: Oxford Uni. Press.

Süß D. 2011, Tod aus der Luft. Kriegsgesellschaft und Luftkrieg in Deutschland und England, Munich: Siedler.

Vogelsang R. 1994, Der Bombenkrieg und seine Auswirkungen auf Bielefeld, «Ravensberger Blätter», (1): 1-12.

von Roques K. 1937 (1934), Die Grundfragen des Selbstschutzes, in Knipfer K, Hampe E. (eds.) 1937, Der zivile Luftschutz. Ein Sammelwerk über alle Fragen des Luftschutzes, Berlin: Stollwerk, 245-250.

Wiggan M. 2011, The Blackout and the Idea of Community in Britain and Germany, in Baldoli, C., Knapp A., Overy R. (eds.) 2011, Bombing States and Peoples in Western Europe 1940-1945, London: Continuum, 43-58.- 2009, Le guerre galliche di Roma, Roma: Carocci. 